for the most part on the same principles, no longer new, but still vital. Prof. Andrade's new book, "An Approach to Modern Physics", reflects the change. It is based on the earlier book, incorporating new material on such branches of physics as nuclear structure, elementary particles, and solids and liquids, in which considerable advances have been made in the past thirty years.

The scheme of the book is to single out a few of the basic conceptions of physics, and to devote a chapter to each. This approach gives a broad historical perspective of the development of physics without being circumscribed by chronology. The many interrelations between the ideas of the different chapters are admirably worked in. It starts and ends with philosophical chapters. "What is physies?" is the question answered in the first chapter. The leading ideas of nineteenth- and twentieth-century physics - the nature of heat and of light, waves, electricity and atoms, quanta, the structure of the nucleusare then introduced. The later chapters become more factual (for example, there is an account of the working of nuclear reactors), more concerned with reporting recent advances, and less reflective. The final chapter ("Uncertainty") is metaphysical, and an affirmation of a personal faith into which is interwoven a somewhat perfunctory discussion of the philosophical problems raised by quantum physics.

It is a pleasure to be able to read a popularization of physics so well thought out and written. It demonstrates that science and literature can still be combined in one work. The approach is often fresh, and the language always simple and graceful, without giving false impressions. The standard of excellence is by no means uniform, however, and one cannot resist the impression that the later chapters have received less polish than the earlier ones, letting in a few mis-statements and some rather facile judgments not in keeping with the standards of the earlier part.

I recommend the book both to the layman and to the student of science. The one will find in it a very readable account of the important concepts of physics; and the other will be made to see familiar ideas with a sharpened perception.

M. H. L. PRYCE

\section{THE HARVEY SOCIETY OF NEW YORK}

The Haryey Lectures, Series 50 (1954-1955)

Delivered under the auspices of the Harvey Society of New York. By Dr. Vincent du Vigneaud, Dr. Richard J. Bing, Dr. J. L. Oncley, Prof. André Lwoff, Dr. Ephraim Shoir, Dr. George O. Gey, Dr. Bernard D. Davis, Dr. David Shemin, and Dr. Eugene L. Opie. Pp. viii +421 . (New York: Academic Press, Inc.; London: Academic Books, Ltd., 1956.) 8 dollars.

THE Harvey Society of New York was founded fifty-two years ago with the object of fostering "the diffusion of scientific knowledge in selected chapters in anatomy, physiology, pathology, bacteriology, pharmacology, and physiological and pathological chemistry, through the medium of public lectures by men who are workers in the subjects presented". These laudable aims have been faithfully pursued, and realized, since the foundation of the Society, as testified by a complete list of the lectures in each year since $\mathbf{1 9 0 5}$, which is included in the present volume. The Society has been admirably served by men of eminence in the various fields, and the titles of past lectures form an interesting reflexion of the climate of thought in the medical sciences over a period of great activity and progress. The collected lectures for 1954-55 illustrate the wide field covered by the Society, and in this series the emphasis rests to a considerable extent on metabolic and biochemical aspects, with considerable attention to bacteriological and cytological aspects. Specifically, the contents contain accounts of lectures on the hormones of the posterior lobe of the pituitary gland, heart metabolism, lipoproteins of human plasma, viral diseases of bacteria, metabolism of ferritin, continuous culture of normal and malignant cells, biochemical applications of bacterial mutants, porphyrins, and the conditions determining water movements into and out of cells. In addition, an address on the Harvey Society, on the occasion of its fiftieth anniversary, is included in this series. It would perhaps not be ungracious to note a slight geographical inaccuracy in the text, in which Lord Adrian is described as Master of Trinity College, Oxford. The format is attractive, there are adequate numbers of diagrams and illustrations, and although the material is, in places, highly concentrated, the spirit of the original lectures would appear to have been retained.

To the busy worker in a particular field, the accessibility in one volume of a wide variety of authoritative reports of recent work is an encouragement to wider appreciation of selected fields of effort, which is regrettably becoming progressively more difficult to realize.

W. BurNS

\section{LOVE AND SOCIETY}

The Direction of Human Development

Biological and Social Bases. By Prof. M. F. Ashley Montagu. Pp. xi+404. (London: C. A. Watts and Co., Ltd., 1957.) 28s. net.

THE study of human behaviour and the structure of human societies, in ways that are in keeping with the requirements of scholarship and scientific inquiry, has always tended to be overshadowed by the speculations of those who feel themselves burdened with a mission for the reformation of the world around them or possessed with an insight which gives them a unique clue to the springs of human behaviour. Sometimes, indeed, the social 'scientist' becomes a propagandist or a prophet, and a muddle is thus created which may cause confusion in the minds of his colleagues and students. Another example of this kind is now presented to us in the work of Prof. Ashley Montagu, director of research, New Jersey Committee for Physical Development and Mental Health. His book is based on lectures given in 1944, in what has since become the Harvard University Department of Social Relations. In the course of delivering them, Prof. Montagu found that human nature became understandable to him for the first time; after ten further years of deliberation he has produced what is stated on the dust cover of the book to be an approach to "a scientific validation of the importance of love in all human affairs". His end is propagandist, but his method is pseudoscientific ; he faces himself with the task of distilling 